\title{
Learning Landscapes: Playing the Way to Learning and Engagement in Public Spaces
}

\author{
Brenna Hassinger-Das 1,* (D), Andres S. Bustamante ${ }^{2}$, Kathy Hirsh-Pasek ${ }^{2,3}$ and \\ Roberta Michnick Golinkoff ${ }^{4}$ \\ 1 Psychology Department, Pace University, New York, NY 10038, USA \\ 2 Department of Psychology, Temple University, Philadelphia, PA 19122, USA; \\ andres.bustamante@temple.edu (A.S.B.); khirshpa@temple.edu (K.H.-P.) \\ 3 Center for Universal Education, The Brookings Institution, Washington, DC 20036, USA \\ 4 School of Education, University of Delaware, Newark, DE 19716, USA; roberta@udel.edu \\ * Correspondence: bhassingerdas@pace.edu; Tel.: +1-212-346-1507
}

Received: 3 May 2018; Accepted: 21 May 2018; Published: 23 May 2018

\begin{abstract}
Children from under-resourced communities regularly enter formal schooling lagging behind their peers. These deficits in areas such as language development, reading readiness, and even in the kind of spatial skills that predict later mathematical knowledge, may persist throughout their lifespan. To address such gaps, policymakers have focused largely on schooling as the great equalizer. Yet, children only spend $20 \%$ of their waking hours in school. How can developmental scientists and educators address this "other $80 \%$ " for the benefit of children's development? One answer is the Learning Landscapes initiative, which involves crafting carefully planned play experiences that focus on learning outcomes, particularly for children and families from under-resourced communities. Playful learning, a broad pedagogical approach featuring child-directed play methods, provides a unique way to foster learning and engagement organically within the built environment. Learning Landscapes already incorporates several well-documented projects. The Ultimate Block Party brought over 50,000 people to Central Park to engage in playful learning activities. Supermarkets became hotspots for caregiver-child interaction by simply adding prompts for caregiver-child interaction through signage in everyday "trapped" experiences. Urban Thinkscape transformed a bus stop and adjacent lot into a hub for playful learning while families were waiting for public transportation. Finally, Parkopolis is a life-size human board game that fosters STEM and reasoning skills in public spaces. This paper reflects on data from these projects while reflecting on lessons learned and future directions.
\end{abstract}

Keywords: playful learning; early childhood; urban planning; design

\section{Introduction}

For decades, communities across the globe have been plagued by inequities between lowand higher-income families [1-3]. Young children from under-resourced communities regularly enter formal schooling lagging behind their peers, and these deficits in areas such as language development [4], spatial skills [5], and early numeracy [6] can set children's learning trajectories through formal schooling and beyond. To address such gaps, policymakers' have largely focused on schooling as the great equalizer. If only society can get children into high quality preschools, this may dilute-if not dissolve- the inequities [7]. This is indeed a key part of the solution, with high quality preschool programs demonstrating meaningful advancement for children in a variety of United States cities $[8,9]$. 
However, children around the world spend varying amounts of time in the classroom. Given that children in Western countries, for example, only spend about twenty percent of their waking hours in school [10], time spent at home and in community settings also offers important learning opportunities to supplement and extend school learning. These settings may also be employed to the foster development of a breadth of 21st century skills, including collaboration, communication, content (e.g., literacy, math, science), creativity, confidence, and critical thinking, to evaluate and apply knowledge in ways that meet the demands of a changing social and economic landscape [11].

A significant portion of the "other $80 \%$ " of children's waking time is spent in home and community settings. Community spaces, in particular, are often underutilized and opportunities for learning are overlooked. Might we be able to marry playful learning, a broad pedagogical approach featuring child-directed play methods [12], with placemaking in ways that infuse underutilized community spaces with learning potential? This is the goal of Learning Landscapes-to enhance community engagement and increase children's learning through caregiver-child interactions-by bringing educational opportunities into public spaces in cities-where $70 \%$ of children are projected to live by 2050 [13].

By focusing on public spaces, the Learning Landscapes initiative is located at the intersection of the push for increased educational equity and the Conscious Cities movement. Started by architect Itai Palti and neuroscientist Moshe Bar in 2015, the Conscious Cities movement aims to create intuitive, responsive, people-centric cities using cognitive science, artificial intelligence, and technology. Researchers involved in Conscious Cities are investigating that ways in which learning and development are influenced by the built environment [14]. Play has been identified as one way to bring people together to use public spaces and interact in ways not done previously [15].

U.S. cities are thriving in many sectors, yet many continue to struggle with education rankings and opportunities for children and families. These cities in particular are well positioned to demonstrate and profit from the concept of Learning Landscapes. The challenge is to unite these efforts around initiatives that are systemic, organic, and supportive of learning in both formal and informal environments, creating a "surround sound" learning experience. With early childhood research indicating the link between various playful learning approaches and increased skill development, now is the time to transform cities into holistic agents of change to support children's learning through increased caregiver-child interactions.

Another benefit of this initiative is that philanthropic support is only needed to achieve proof of concept. After that point, data that demonstrates this type of community-level change will make a compelling case to embed Learning Landscapes into city budgets, providing a sustainable and scalable way for the public to invest in city rejuvenation, revitalization, and in the children who will become productive citizens of the 21st century. Consistent with existing efforts like Urban95 from the Bernard van Leer Foundation - designed to tailor urban environments to the needs of young children-Learning Landscapes extends this work in public spaces by turning ordinary spaces throughout the city into extraordinary opportunities for interaction, engagement, and learning. At the broadest level, Learning Landscapes enhances civic engagement and adult learning about the role they can play in educating their children, all while developing the concept of a conscious city that is responsive to the needs of its citizens.

\subsection{Why Playful Learning?}

Research shows that young children learn best in active, meaningful, engaged, and socially interactive contexts [16]—-making play an ideal setting for enriching opportunities that will augment children's educational development [17]. During active learning, children are "minds on", or actively participating in a task rather than passively observing, and they are thinking and reasoning rather than just mindlessly doing a task $[18,19]$. Engagement in a learning activity is also essential, as studies have consistently shown that children learn more when they are paying attention rather than becoming distracted [20-23]. Additionally, children learn more effectively when learning material is meaningfully 
connected to their lives, or is related to something they already know, rather than presented abstractly and out of context $[24,25]$. Finally, a wealth of evidence suggests that children learn more when they interact with others than when they do not [26-28].

To capitalize on the ways children learn best, playful learning includes the methods of free play, guided play, and games. Free play, whether with objects, pretend, or physical, is fun and voluntary, involves active engagement, without extrinsic goals, and often incorporates make-believe [29,30]. During free play, children can engage in discovery learning and practice social and other skills without constraints from adult involvement [31]. Henricks [32] described play as a "laboratory of the possible", (p. 168) and as such, it appears that the flexible context of play allows children to encounter situations and enact behaviors that contribute to their scientific reasoning abilities [33]. For example, object play helps children to uncover how the world works in tangible, tactile ways [34], including understanding cause-and-effect relationships [35] and discerning the causal structure of objects through learning about affordances of object features [36]. Science learning is partially driven by scientific curiosity, or the levels of uncertainty that lead children to explore an unfamiliar topic [37]. Children are motivated to discover how things work and to use object play to satisfy their scientific curiosity by asking questions [38], devising spontaneous experiments, and learning about causal relationships through interventions $[35,39,40]$.

Guided play retains many characteristics of free play, especially the enjoyable nature and the fact that it is child driven, but adds an additional focus on a targeted learning goal [41]. Guided play involves children exploring their environment with adults through interactions focused on implicit learning goals [12]. It allows children to tinker in a constrained environment that encourages independent exploration informed by adult expertise [17]. Adults support a learning goal by using strategies including commenting and asking open-ended questions about children's ideas [12] and fostering the serve and return interactions that are critical for development. For instance, guided play improves language outcomes $[42,43]$ by providing a meaningful context for the use and extension of words. Additionally, Fisher and colleagues [44] found that guided play promotes children's learning about geometry and shapes better than didactic instruction or free play.

Finally, when games are combined with educational content, they enhance learning by increasing children's motivation, which increases their attention to content and helps them retain more information $[45,46]$. For example, one study examined a board game, similar to Snakes \& Ladders, that was combined with shared book-reading for the purposes of improving four-year-olds' vocabulary knowledge [47]. Results indicated that children who played the experimental board game gained more receptive and expressive vocabulary knowledge than children in the control condition, who received equal word exposures but did not play the experimental version of the game. Similarly, Ramani and Siegler [48] found that playing a linear number board game improved low-income preschoolers' mathematical knowledge in the areas of numerical magnitude comparison, number line estimation, counting, and numeral identification.

Play experiences may also help connect individuals with the places around them and reinterpret ways to use public space [15]. In particular, playful learning can offer a unique way to foster learning and engagement with the built environment. Incorporating playful elements into architecture and public space also promotes curiosity and a desire to learn. This is critical, because learning and development are significantly impacted by individuals' and families' environments [49]. The physical environment can influence internally-driven curiosity, through the creation of a mise en place - a disposition and readiness to engage in and explore a learning activity [50]—while also encouraging caregiver-child discourse and engagement in activities involving language, mathematics, and spatial topics.

To ensure high quality playful experiences, it is also important to understand caregivers' attitudes about the links between play and learning. Many caregivers do not always see the connection between the two, since although important for cognitive and social development, play has been dropped precipitously from preschool and kindergarten classrooms [51]. A false dichotomy prevails, presenting 
play and learning as mutually exclusive $[29,52,53]$. Little research, however, has explored the ways in which caregiver attitudes can be enhanced or changed to align with scientific evidence about the importance of play.

\subsection{Taking a New Approach}

By transforming public spaces into opportunities for caregiver-child interaction and playful learning, the Learning Landscapes initiative treats learning as a public health issue and not simply an educational one. As more research on the negative impacts of poverty on children's brain development comes out [54,55], it is becoming increasingly clear that a public health approach is warranted. Thus, our approach is similar to the one taken by researchers who have examined the role of public spaces in increasing exercise opportunities. Several studies have demonstrated the important role of parks for physical exercise in the pursuit of improved population health [56-58]. By putting exercise equipment in public parks, parks are used more frequently and also increases physical activity levels in comparison to parks without exercise equipment [59]. The simple act of changing the public space resulted in measurable changes in people's behavior.

Within the education sphere, past approaches, both school- and home-based, in areas such as mathematics and reading, have not significantly turned the tide to positively impact achievement gaps. One potential reason for this lack of impact is that a higher dose of exposure is likely necessary to create change. By introducing playful learning experiences into "the other $80 \%$ ", Learning Landscapes can create opportunities for additional exposure to learning. Learning Landscapes is non-traditional, in that it does not take place in laboratories with tightly controlled conditions or in classrooms. In the real world, it is not possible to employ methods with this level of control. Yet, Learning Landscapes can collect objective, real-time observational and survey data that demonstrate how families and children use the spaces and how discourse and interaction are affected by the installations. In the spirit of community-based participatory research, projects within the initiative also include community members as paid data collectors. This helps to increase neighborhood buy-in and provides employment and job skills to motivated neighbors. At the same time, community data collectors are more likely to have a rapport with families visiting the Learning Landscapes sites and may be more able to obtain consent for partaking in surveys than non-resident university student research assistants.

The fitness equipment example and others suggest that there can be real change by targeting community contexts. Despite Herculean approaches by the field to narrow achievement gaps, we have seen only minimal outcome changes. Yet, recent data are encouraging, suggesting that some of the more community-wide efforts like Vroom - an app designed to bring the science of brain development for young children to families and communities [60]—or Too Small to Fail—a public awareness and action campaign from the Clinton Foundation and The Opportunity Institute giving caregivers tools to talk, read, and sign with their young children-are part of the solution. Since 1998, the reading skills gap has been reduced by 16 percent and the mathematics skills gap has been reduced by 10 percent at the start of kindergarten [61]. One suggested reason for this reduction is an increase in engagement with caregivers, both in and outside the home. Learning Landscapes fits squarely within these types of initiatives.

\subsection{Learning Landscapes Initiative Structure}

Learning Landscapes is deeply informed by the latest findings in developmental science and guided by a theory of change that embraces the need to alter environments in ways that will support caregiver attitude change and child outcomes. The theory of change (Figure 1) suggests impact at multiple levels including galvanizing support from community leaders for city-wide initiatives in early learning and galvanizing neighborhoods around more localized opportunities for learning.

The theory of change starts with the strategies of the project, including altering public space, encouraging positive use of public space, adding playful learning installations to the environment, and engaging and welcoming community members, families, and children. Learning Landscapes 
targets caregiver learning beliefs, dyadic communication while at the Learning Landscapes sites, dyadic interaction while at the sites, as well as community engagement, buy-in, and commitment. The ultimate goals of the initiative are to embed active, engaged, meaningful, and socially interactive learning opportunities in public spaces with an eye toward changing outcomes in what Golinkoff and Hirsh-Pasek [11] call the 6Cs-collaboration, communication, content, critical thinking, creative innovation, and confidence. The $6 \mathrm{Cs}$ highlight the need for twenty-first century education to focus on more than test scores and memorization; to be successful in today's dynamic world, children need to exhibit the qualities embodied by the 6Cs. More specifically, Learning Landscapes targets changes in caregivers' behaviors like increased ability to support their children's play and greater confidence in having quality conversation and interactions with their children as well as increases in the 6Cs in areas including children's play skills, school readiness, socioemotional skills, scientific curiosity, and school achievement. At the dyad level, Learning Landscapes ultimately aims to increase both communication and interaction-generalizing to locations and situations not involving Learning Landscape sites. Much research indicates that caregivers' beliefs about play and learning guides their interaction with their children [62-64] and that changing the attitude of parents who believe that learning only takes place in school is very important for children's development.

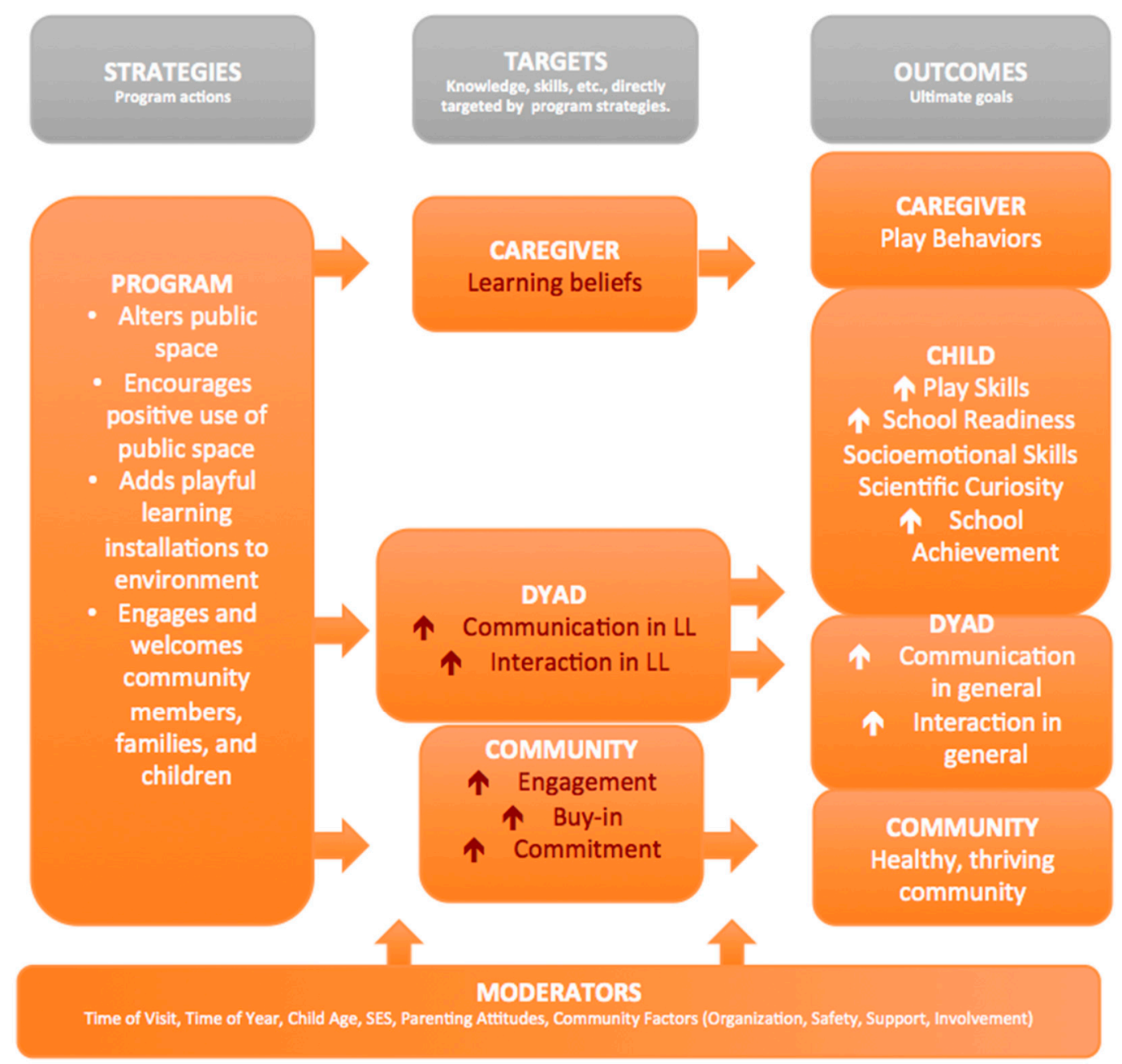

Figure 1. Learning Landscapes Theory of Change.

Finally, the end goal for the community as a whole is creating communities intentionally designed for play and learning. Throughout the process, moderators at all levels, including time of visit/year, child age, socioeconomic status, caregiving attitudes, and the community factors of organization, 
safety, support, and involvement, affect progress. These moderators are critical factors that will be addressed in the description of each Learning Landscape example project.

Learning Landscapes is a bold, visionary initiative that is multidisciplinary at its core and offers a new approach to the other $80 \%$ that supports the kind of caregiver-child interactions that promote learning that young children need for school success. It does so, however, in a fun and inviting way that is built upon the foundation of the learning sciences. By using cities as agents of change, Learning Landscapes taps into the renewed focus on education while also contributing to the movement promoting family-friendly cities. This initiative also offers a new lens for viewing the ways in which we think about informal education for children.

In this paper, we highlight several projects that comprise Learning Landscapes at this point. Projects generally focus on families with children zero-eight, with older children and caregivers involved as well. Learning Landscapes projects have been implemented in New York City, New York, Philadelphia, Pennsylvania, and Wilmington, Delaware. They are also on-going in Tulsa, Oklahoma, and Johannesburg, South Africa. We will also present new data from a project in Switzerland.

\section{Learning Landscapes Projects}

\subsection{Ultimate Block Party: Is It Possible to Bring People together in a Public Space to Explore Playful Learning?}

The Ultimate Block Party (UBP) [52,65] served as the first pilot test for Learning Landscapes. UBP sought to transform caregiver attitudes about the relationship between play and learning in a community setting. The inaugural event of the UBP initiative was held in Central Park, New York City on 2 October 2010, and attracted over 50,000 participants. The UBP targeted caregiver knowledge of the science of learning through 28 activities that spanned eight play domains, including adventure, construction, physical, the arts, make-believe, technology, and language play [65]. All activities were based on research from the learning sciences about how to target specific skills. For example, the LEGO Extravaganza event was built around research that shows block play relates to spatial and mathematics skills [5]. Scientists dotted the park to make clear the learning connections embedded within each activity. Event organizers also handed out 16,000 handbooks, which described the ways to take home the learning happening at UBP.

An evaluation team, headed by researchers from Sarah Lawrence College and Yale University, conducted 292 in-person interviews (258 with UBP participants and 34 with a control group of caregivers in Central Park) and a web-based survey of UBP volunteers $(\mathrm{N}=57)$. The goal of the evaluation was three-fold: (1) to measure the UBP event's success in conveying 4 core messages about play to caregivers; (2) to determine how well the UBP event's organization supported achievement of its goals; and (3) to learn about people's general attitudes with respect to play in order to inform future strategy for the UBP initiative and other forms of play advocacy. With regard to the measurement of caregiver attitudes, the researchers designed a short survey featuring Likert scale items, open-ended questions, and demographic questions to assess caregiver attitudes and beliefs about play and learning [52]. Results suggested that caregivers' ability to represent different facets of the play/learning connection is a vital component in public awareness and may have been strengthened through direct exposure to multiple forms of play [52]. Results also demonstrated that caregiver attitudes about play could be changed after visiting as few as three playful activities. In the following years, UBPs have also taken place in Toronto, Ontario, Canada and Baltimore, Maryland.

The success of UBP demonstrated that the general populace is deeply interested in the construct of playful learning. This could be a conduit for changing attitudes, behaviors, and outcomes for children and families. Such findings emboldened us to then develop a more targeted approach to bringing the science of learning into community settings. 


\subsection{Supermarket Speak: How Can "Trapped Spaces" Be Infused with Learning Opportunities?}

And yet, UBP was a destination. Families had to make a special trip to Central Park to experience the playful learning activities. For the next instantiation of Learning Landscapes, we selected to infuse a space where families regularly go with opportunities for learning and interaction. Supermarkets are an example of a "trapped space" where people spend time waiting or going about daily activities in a closed space. To reach families while they do their grocery shopping, it is important to consider the ways in which adults navigate the store-we are mindful that they likely want to get in and out as fast as possible-while also offering ways for adults to engage children in fun and educational interactions. At the same time, supermarkets are already rich in opportunities to target language and mathematics skills, such as counting the number of apples a family would like to purchase or learning the names for fruits and vegetables. Thus, we asked how we might capitalize on these latent learning opportunities already present within supermarkets.

In this study, we built playful learning into local supermarkets to spark higher caregiver-child interactions [63]. Research demonstrates that everyday conversations between caregiver and child are important to language learning, which predicts school readiness [64,65]. Additionally, increased quality and quantity of caregiver-child conversation can combat the language disparities between children from low- and higher-income backgrounds [66-68]. However, interventions that target caregiver-child interactions are often expensive, labor-intensive, and difficult to integrate into disadvantaged families' lives-resulting in high attrition rates $[69,70]$.

In response to these challenges, our research team implemented a novel and subtle intervention-signage - which attempted to reach caregivers and children in supermarkets. Colorful, visually attractive signs (Figure 2) transformed the supermarkets into children's museums and used these everyday environments as springboards for learning as well as caregiver-child conversations and interactions.

Signs were posted in supermarkets in Philadelphia, Pennsylvania, in neighborhoods serving families from low- and middle socioeconomic backgrounds. Research assistants conducted naturalistic observations of adult-child groups when signs were and were not posted.

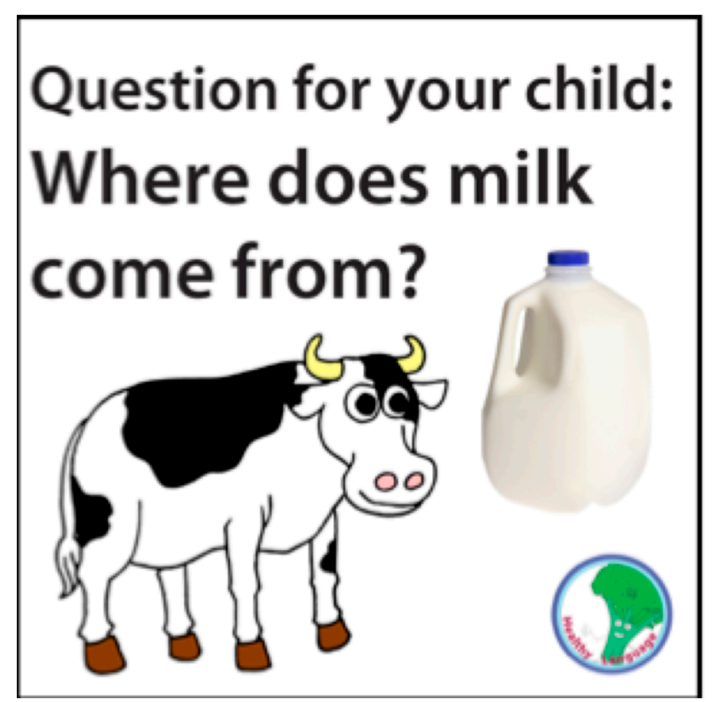

(a)

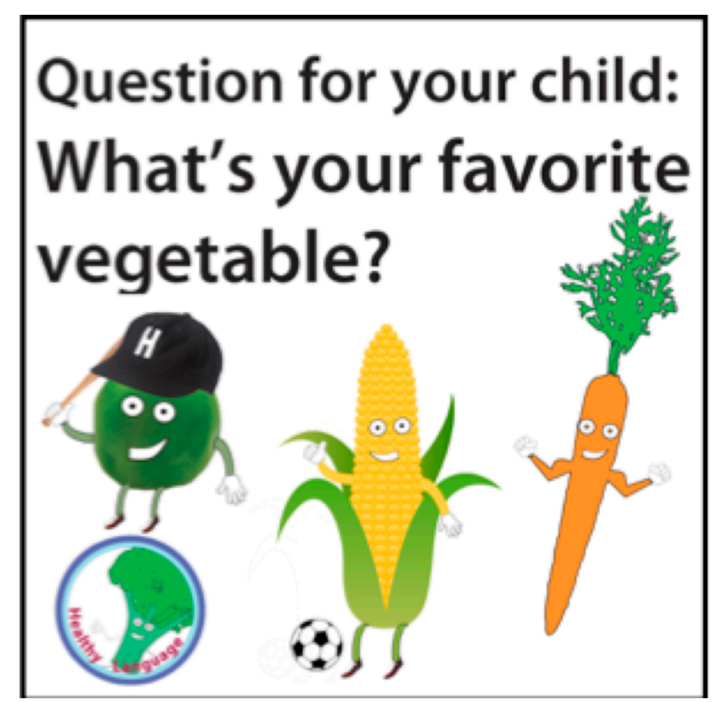

(b)

Figure 2. Example signs from Ridge et al. (2015): (a) dairy case sign and (b) produce aisle sign.

Then, a Total Interaction Score was computed for each adult-child group, composed of indicators of rich caregiver-child interactions including: amount and valence of interaction, number of adult and child-initiated questions, and types of language used (e.g., descriptive or informative). The coding 
scheme was derived from Dyadic Parent-Child Interaction Coding System, validated to assess quality of caregiver-child social interaction [71], as well as other caregiver-child interactions [67,72-74].

Families shopping in the low-SES neighborhood interacted less when signs were not posted than families in the mid-SES neighborhood. Adding signs however, resulted in families from low-SES backgrounds talking significantly more, and erasing the gap between them and mid-SES families. Overall, there was a 33\% increase in these language interactions in the low-income neighborhood supermarket. Adults used significantly more descriptive language, asked the child more questions, said the name of the product more to their child, and showed the product more to the child. Children pointed to products more and asked the adult significantly more questions. The presence of the signs did not make a significant difference in caregiver-child conversations and interactions occurring in a supermarket located in a middle-income neighborhood. By using "trapped" spaces where caregivers and children go-we sparked precisely the kinds of interactions that build a foundation for strong language development.

This work is currently being replicated in Johannesburg, South Africa and in Tulsa, Oklahoma. As a part of the "Talking is Teaching: Talk, Read, Sing" campaign of Too Small to Fail—in conjunction with the George Kaiser Family Foundation, CAP Tulsa, and Tulsa Educare-the Ridge et al. [63] study was replicated in Tulsa, Oklahoma. Similar colorful, visually attractive signs (Figure 3) were posted in supermarkets in both low- and middle-income neighborhoods and Spanish-language signs were posted in a supermarket in a primarily Spanish-speaking neighborhood. Termed "Healthy Language", signs featured both language and mathematics prompts, with the addition of math prompts being novel for this iteration. Morris, Zapata, and Treat [75] led a team that observed English and Spanish-speaking caregiver-child groups $(\mathrm{N}=497)$ before and after signage installation using the same type of observation methods as Ridge et al. [63]. However, unlike in the Ridge and colleagues study, stores designated as low-income actually drew in more economically mixed groups of shoppers, as per shopper surveys. Furthermore, amount of interaction in the signs down conditions were higher at baseline than in Ridge et al., meaning that there were fewer opportunities for growth in caregiver-child interaction. As a result, no statistically significant differences were found in the number of conversational turns before and after signage installation. However, in this setting, researchers found a difference in the quality of conversation from pre-signage to post-signage. After the signage was installed, a greater percentage of adults said the name of products or activities, used numerical language, and talked about colors than before the introduction of signage. Regardless of the presence or absence of signage, Hispanic caregiver-child groups demonstrated higher levels of interaction than non-Hispanic groups.

In Johannesburg, South Africa, South African Partners and researcher Sharon Moonsamy with her team from the University of the Witwatersrand are currently completing an additional replication of Ridge et al. [63]. In addition to language development-focused prompts, this project also added signs with mathematics prompts that targeted numerical and spatial language (see Figure 3 for an example). The signs were posted in supermarkets in both low- and middle-income neighborhoods in both English and isiXhosa. Termed "Sifunda Ngokuthetha" or "We Learn by Talking Together", caregiver-child groups were observed using naturalistic observation, as in Ridge et al. [63], as well as shopper exit surveys asking adults with children which signs they noticed while shopping and what impact the signs had on their shopping experience. Data from this project will demonstrate the effectiveness of translating this intervention into an international context.

Throughout its various iterations, this low-cost, supermarket intervention fosters the type of caregiver-child conversations and interactions that have the potential to impact later language, literacy, and mathematics outcomes for children from disadvantaged backgrounds. Many families from low-income backgrounds do not have the means to regularly visit children's museums and other comparable spaces. By transforming a supermarket into a similar space for learning, the supermarket speak studies convert an everyday place into an enriching learning environment. In this way, supermarket speak harnesses the other $80 \%$ of children's time to improve their academic forecast. 


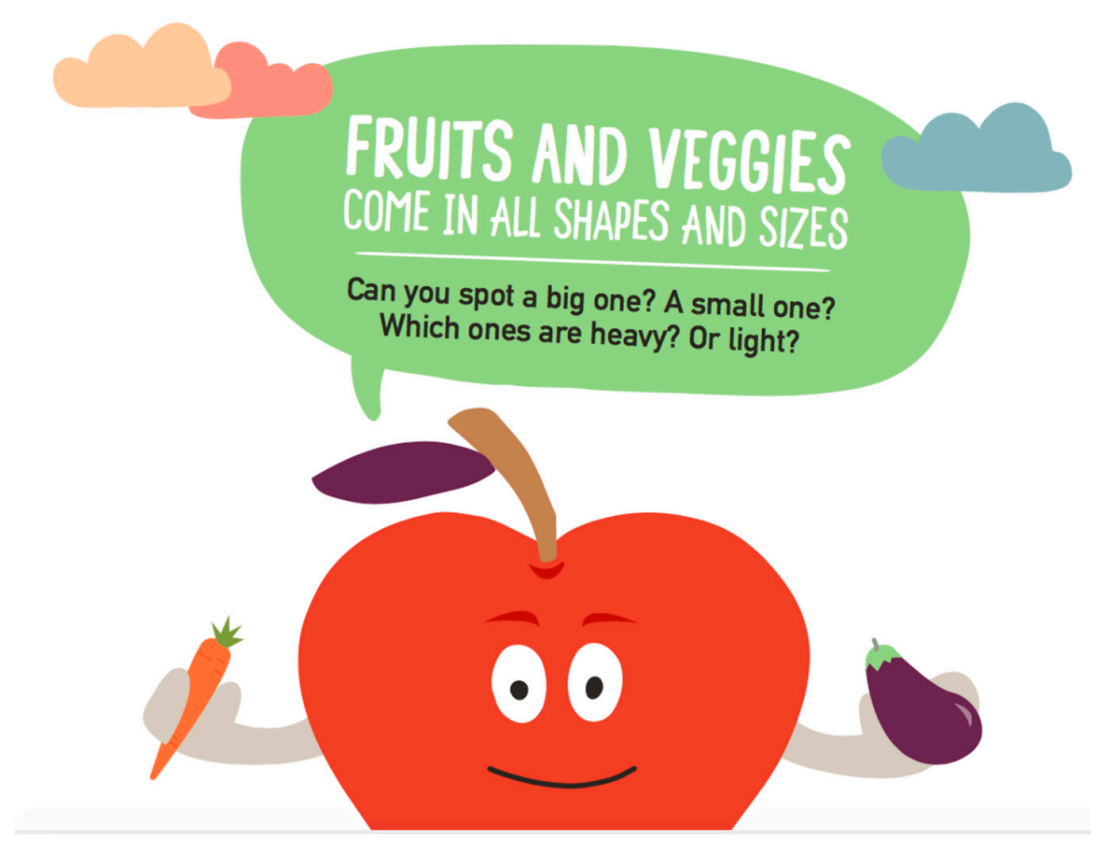

Figure 3. Example sign from "Healthy Language" in Tulsa, Oklahoma.

\subsection{Urban Thinkscape: How Can Public Spaces Be Infused with Learning Opportunities?}

If supermarkets can prompt caregiver-child interaction and learning, then, in theory, public spaces can be equally effective locations for such activities. Today, our public spaces include places where people wait—often with children. Adults are often using their phones or giving their children phones or tablets to occupy them [76]. How can we transform places-from street corners to laundromats-where people gather into hubs for playful learning? Bus stops offer one opportunity to test this idea. We asked whether it might be possible to reimagine a bench as a learning opportunity instead of merely a place to sit and wait for a ride. Urban Thinkscape explored this possibility.

Urban Thinkscape marries architectural design with research from the science of learning. Designed in collaboration with architect Itai Palti of the Conscious Cities movement, it places aesthetically beautiful and exciting learning opportunities directly within cityscapes in the places where people regularly go-at bus stops, on sidewalks, and in parks. Designs installed in the pilot cluster include: Puzzle Bench, Jumping Feet, Stories, and Hidden Figures. The designs were created to tap into active, engaged, meaningful, and socially interactive learning contexts while also targeting specific areas of learning, such as spatial skills, language development, and executive functioning. Puzzle Bench uses the back wall of a bus stop to challenge waiting passengers to complete a series of puzzles (Figure 4). Fostered by puzzles, early spatial and mathematics skills are key predictors of both later mathematics and literacy abilities $[77,78]$. The next design, Stories, asks children to balance from one narrative cue to another to create a story (Figure 5). This activity fosters the development of narrative skills, which impact children's literacy outcomes [79]. With younger children, caregivers can ask them to identify the objects in each narrative cue, building vocabulary and language skills-both precursors to narrative development. The third design, Jumping Feet, morphs everyday hopscotch into an executive functioning activity (Figure 6). Executive functioning is an umbrella term for the control of cognitive processes, including working memory, flexibility, problem solving, and planning. Children's executive functioning abilities in early childhood predict later reading and mathematics achievement better than IQ scores [80]. In the Jumping Feet activity, shoe prints encourage children to jump, developing their ability to control impulses and think flexibly as they match the random pattern and think about their next step. Caregivers can also encourage children to switch up the pattern-signage suggest that they can try putting one foot where they see two and two where they see one, thereby targeting cognitive inhibition. Finally, Hidden Figures activates children's curiosity by 
searching in the metalwork for images of food, animals, and any other objects they can locate (Figure 7). This activity sparks scientific curiosity by introducing a level of uncertainty about how the design creates different images at different times of day. As the sun moves across the sky, different shapes are revealed on the ground below. Building this kind of curiosity leads to exploratory behavior and helps children become strong problem solvers [36]. Children can also develop spatial skills by figuring out how the images are projected onto the ground.

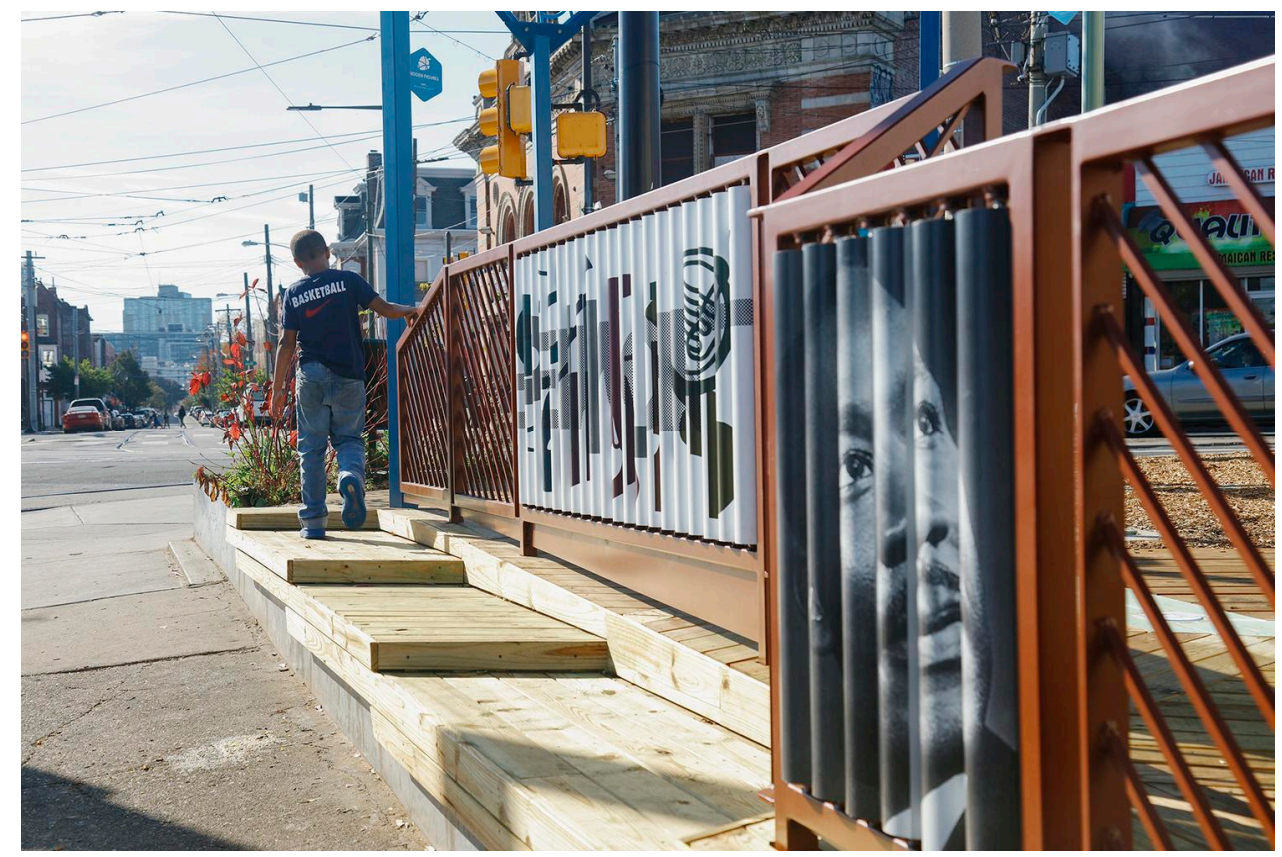

Figure 4. Puzzle Bench design at Urban Thinkscape.

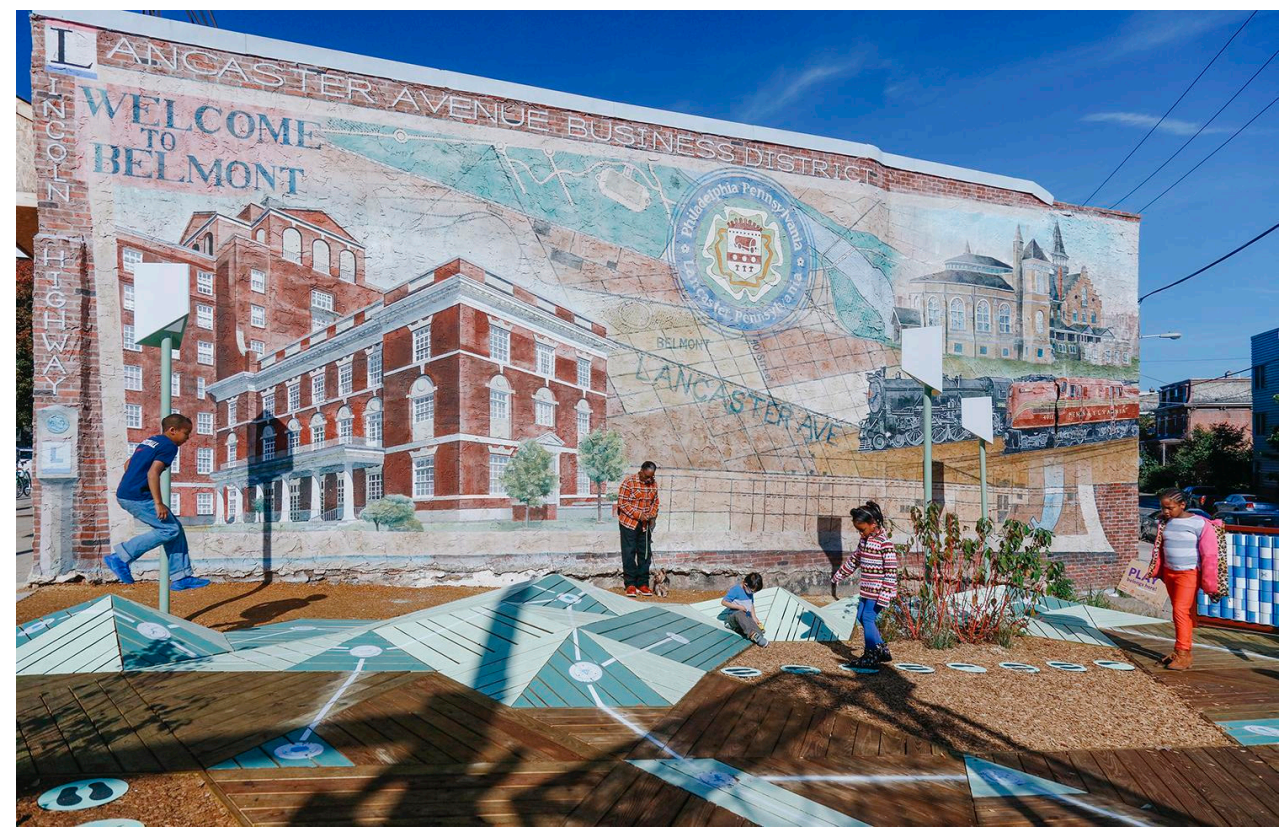

Figure 5. Stories design at Urban Thinkscape. 


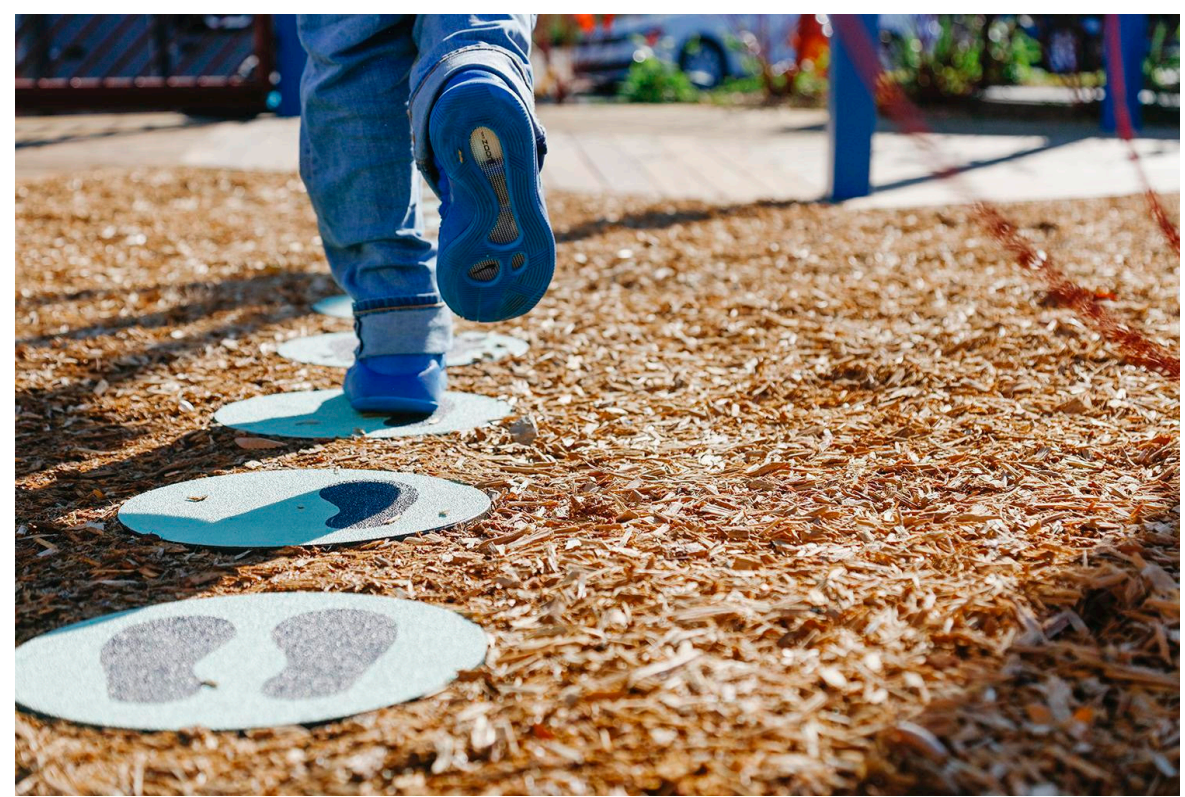

Figure 6. Jumping Feet design at Urban Thinkscape.

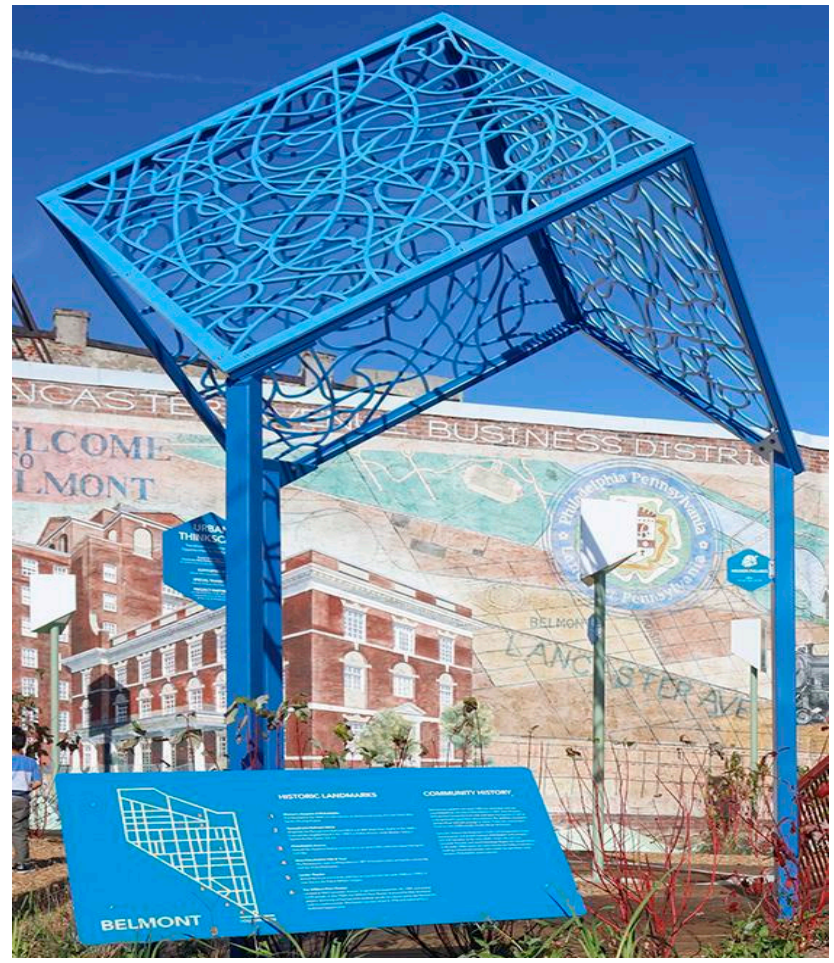

Figure 7. Hidden Figures design at Urban Thinkscape.

The development of Urban Thinkscape started with the principles of how people learn most effectively and how those principles relate to specific content areas of interest. Then, the project team connected with members of the local community to determine what they wanted for their neighborhood. To do this, at the beginning of the project, leaders of neighborhood associations and community groups in the Promise Zone area of West Philadelphia, as well as groups of community members, were invited to attend meetings facilitated by the project team. Community members expressed that they wanted something in the neighborhood that would invite families to come in and 
stay rather than to leave. The project was built with the community, who tailored it to their own specific needs and desires. It is in this way that the project was personalized and owned by the community.

The feedback received from these meetings was given top priority during discussions with city leaders, and as a result, a privately owned lot located in the Belmont neighborhood was selected as the location of the first cluster of Urban Thinkscape designs. The lot is situated near the location where Martin Luther King, Jr. led the "Freedom Now" rally on 2 August 1965. The decision to group designs in a cluster was based on findings from the Ultimate Block Party, which showed that it takes exposure to three-four activities in a group to change caregivers' attitudes towards playful learning [51].

One other critical piece of the project involves community data collectors. Community members are collecting pre- and post-implementation observational and survey data at both the Urban Thinkscape site and a control site playground in the same area. Community members received payment and job training as a part of their participation in the project. Through the observations and surveys, community data collectors gather information about the following goals of Urban Thinkscape: (1) families will be more engaged and interactive with the public space; (2) caregiver-child discourse around public spaces will be increased along with enhanced family interaction; and (3) families will begin to understand and change their attitudes regarding the links between play and learning.

At pre-test, data demonstrated that fewer types of language (and fewer conversations in general) were heard at the future site of Urban Thinkscape than at a playground in the same general area (Figure 8). The control location was chosen since it is one of the playgrounds closest to the Urban Thinkscape site within the Promise Zone area. The goal was to select an existing playspace location where we might capture caregivers and children interacting naturally around play.

Forthcoming post-test data will reveal if the installation of the designs resulted in increases in specific types of adult and child language use at the Urban Thinkscape site.

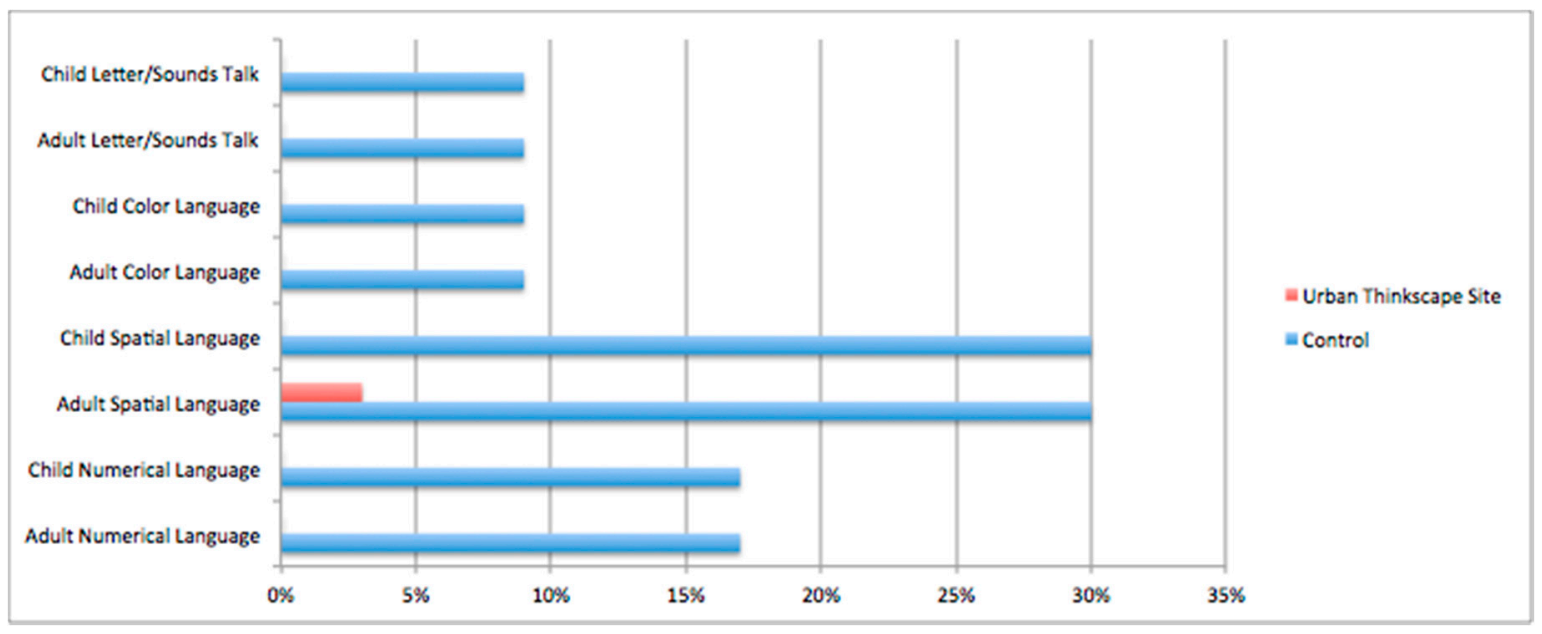

Figure 8. Percent of caregiver-child groups using specific language categories at pre-test.

\subsection{Parkopolis: Can We Enrich Public Spaces Even Further by Building in More Sophisticated Content?}

The above Learning Landscapes projects test the ability to change caregivers' attitudes towards the connection between play and learning, increase caregiver-child discourse and interactions, and engage communities as true partners in the process. Might it be possible to build specific academic competencies that children typically learn in school, in the context of parks and playgrounds? Research on game-based learning demonstrates that indeed games can build key academic skills outside of school [81,82]. In the latest iteration of Learning Landscapes, we endeavor to enrich public spaces with math and science learning opportunities using our life-size playful learning board game-Parkopolis.

Parkopolis targets STEM and domain-general learning skills (e.g., executive functioning, approaches to learning, and fluid reasoning). In Parkopolis, children roll dice to advance around 
the board and draw cards that engage them in different mini-games and activities. Derived from cutting-edge research in the science of learning, Parkopolis is designed to promote engagement and STEM dialogue between caregivers and children. The games and activities that compose Parkopolis are designed to apply principles derived from rigorous research to this new challenge in a manner that is sustainable and scalable.

Research demonstrates that playing linear numerical board games promotes children's math development $[82,83]$ and that children learn more effectively when they engage with their whole body [84-86] rather than when they learn in more passive contexts. Further, fractions are a particularly difficult concept for children in formal school [87]; thus, our game incorporates a redesign of dice that includes fractions - and the spaces of the game board are divided into fourths- this way children can advance two and a half, or three and three-quarters spaces and have an embodied fraction learning experience.

The activities in Parkopolis were born from the scientific literature targeting critical STEM skills that predict later school success; such as, patterns [88,89], numeracy and spatial skills [90-92], geometry [93], measurement [94], and fractions [87,95]. See Parkopolis and fraction dice designs in Figure 9.

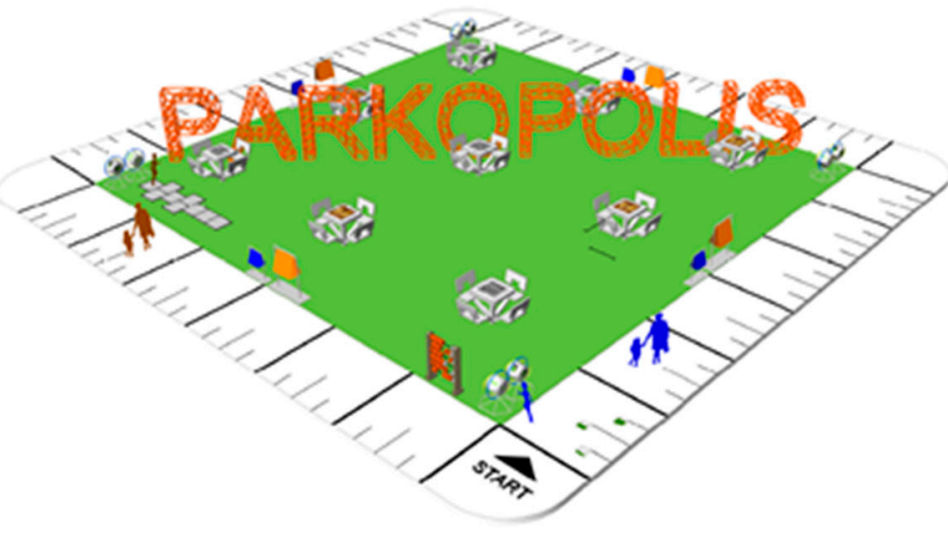

(a)

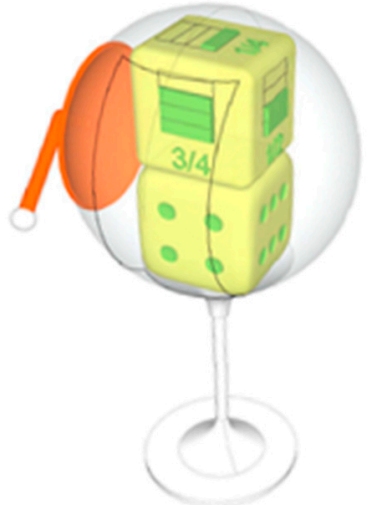

(b)

Figure 9. Designs for Parkopolis: (a) game board; (b) fraction dice.

Parkopolis also pulls from domain-general learning skills that help children learn regardless of the academic content. This includes executive functioning (i.e., working memory, cognitive flexibility, and inhibition; [96]), approaches to learning (i.e., strategic planning, persistence, open-mindedness, sustained focus, communication, and cooperation; [97]), and fluid reasoning, which is the capacity to think logically and solve novel problems, critical for scientific and computational thinking [98]. Finally, Parkopolis promotes physical activity and gross motor skills, which have empirically-demonstrated benefits for children's cognitive and health development $[99,100]$. To generate the game cards we pulled directly from the literature and contacted leaders in the field to ensure the most relevant content was represented. For example activity cards (see Figure 10).

The first pilot study of Parkopolis was conducted across three summer camps in Lausanne, Zurich, and Zug, Switzerland, in August 2017. We observed 35 small groups of children (4-6 children per group) either playing Parkopolis $(n=28)$ or playing an outdoor game of their choice $(n=7)$. In total we observed 158 children ranging from 8 to 13 years of age $(M=11.1)$, they were $32 \%$ female $(n=50)$, and $94 \%$ White $(n=148)$. 


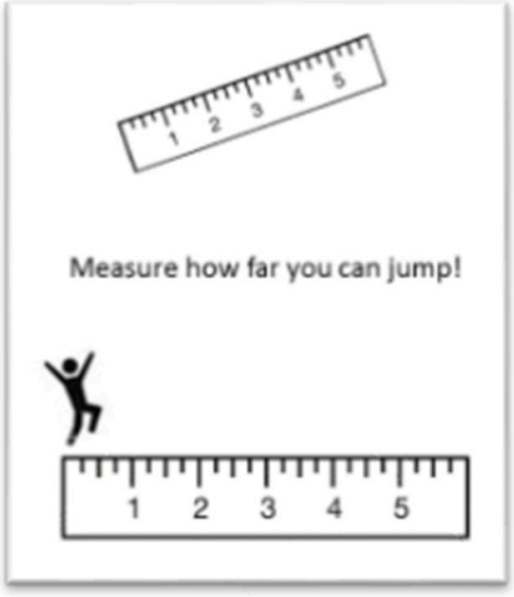

(a)

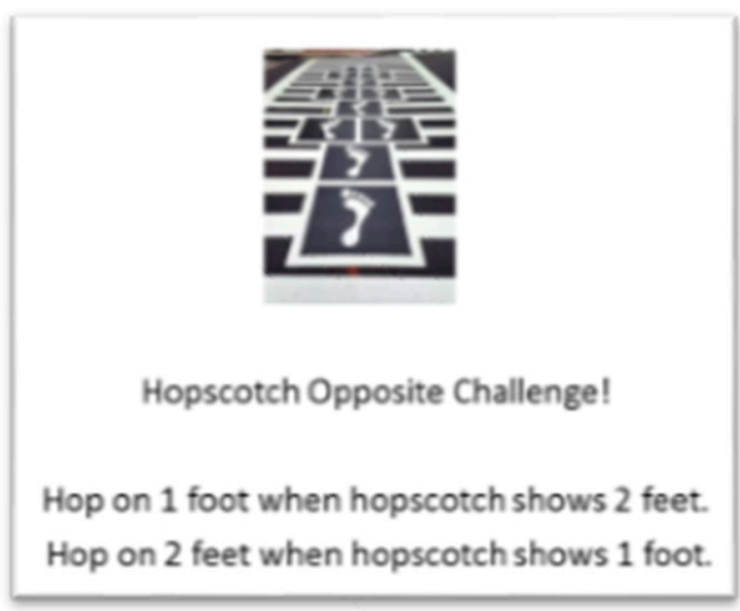

(b)

Figure 10. Example activity cards from Parkopolis targeting measurement (a) and executive functioning (b).

To capture children's language, engagement, and approaches to learning we adapted an observational protocol from a previous Learning Landscape study [79]. Observers rated children's STEM language use (e.g., numeracy language, fraction language, spatial language, and measurement language) on a Likert scale ranging from 1 (0 utterances) to 5 (16+ utterances). Double coded observations showed $91 \%$ agreement $( \pm 1)$ on the 5-point scale indicating strong inter-rater reliability.

Compare to the control condition, children playing Parkopolis used significantly more whole number language $(\mathrm{t}(33)=5.68, p<0.01, d=1.55)$, fraction language $(\mathrm{t}(33)=2.77, p<0.01, d=1.50)$, spatial language $(\mathrm{t}(33)=3.16, p<0.01, d=1.43)$, measurement language $(\mathrm{t}(33)=3.46, p<0.01, d=1.87)$, and made more observations $(\mathrm{t}(33)=2.03, p=0.05, d=0.84)$ (see Figure 11). Similarly, children playing Parkopolis were more engaged $(\mathrm{t}(33)=2.20, p=0.03, d=0.67)$, showed greater confidence in dealing with complexity $(\mathrm{t}(33)=5.84, p<0.01, d=1.80)$, and persistence in working with difficult problems $(\mathrm{t}(33)=3.98, p<0.01, d=1.45)$, compared to the control condition.

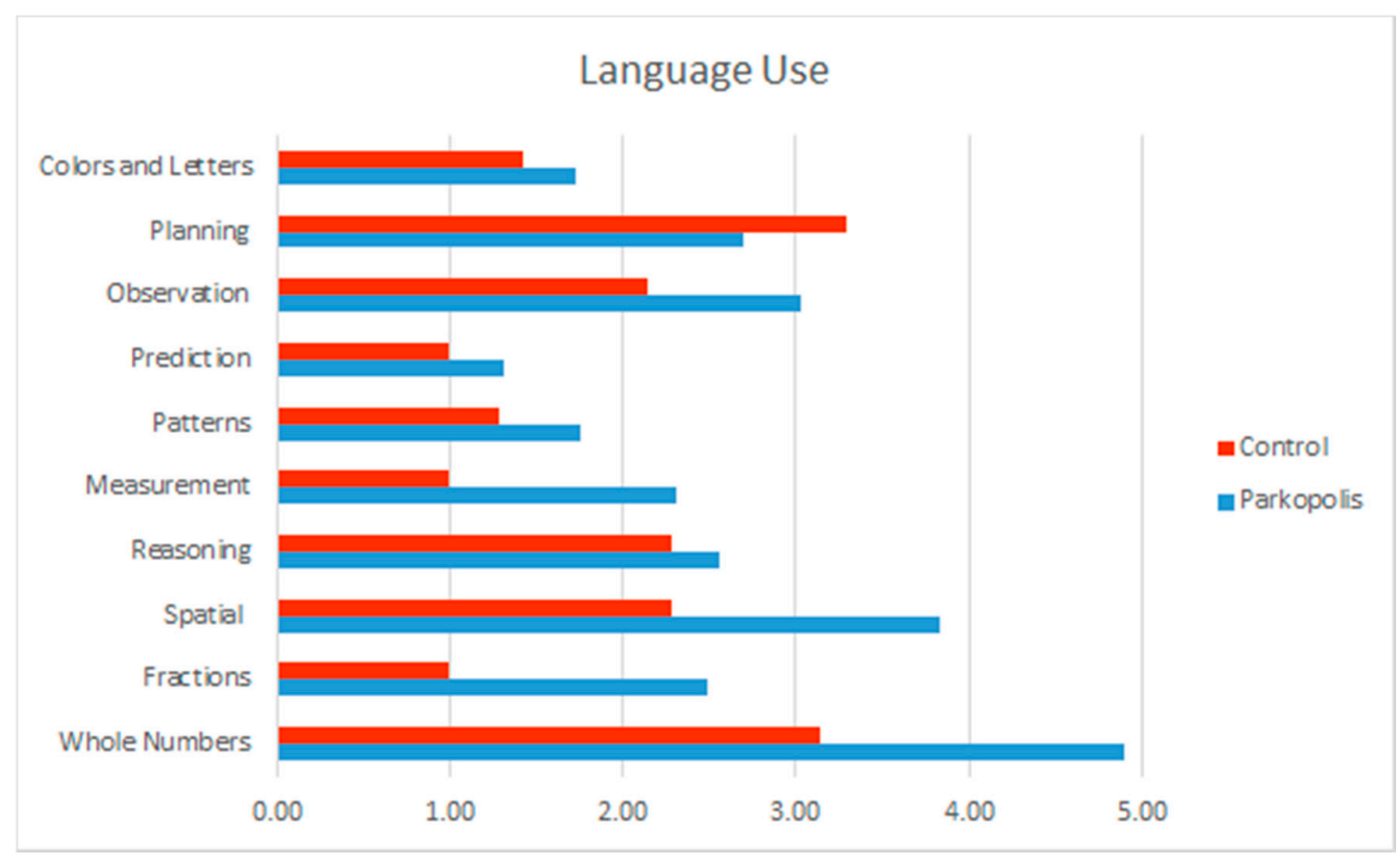

Figure 11. Mean language use in the Parkopolis and Control conditions. 
However, there were no significant differences between Parkopolis and the control condition in children's reasoning language $(t(33)=0.63, p=0.54)$, talk about patterns $(t(33)=1.27, p=0.21)$, predictions $(\mathrm{t}(33)=1.26, p=0.22)$, planning $(\mathrm{t}(33)=-1.25, p=0.22)$, and talk about colors and letters $(t(33)=0.67, p=0.51)$. Additionally, Parkopolis showed no significant advantage over the control condition in children's turns during verbal interactions $(\mathrm{t}(33)=0.64, p=0.53)$, amount of interaction $(t(33)=0.93, p=0.36)$, and physical activity $(t(33)=1.60, p=0.11)$. Finally, there was no difference between Parkopolis and the control condition in children dealing with open-ended problems, and communicating/working with others, as all groups were rated to have engaged in these activities.

These pilot data demonstrate that Parkopolis successfully targeted STEM content. It also showed the ability of the game to engage children and provide a platform for them to exercise their approaches to learning and executive functioning skills. A key development goal of Parkopolis was to design the game to be very intuitive so that children and families could play with minimal written instruction and no supervising staff to explain or facilitate the game.

While encouraging, this pilot study also had several limitations. First, the concept for the game was designed for installation in urban low-income environments. However, the campers in this study came from families that could afford to send them to a private summer camp. Further, children in the camps were on the older end of the age spectrum that we intend to target with Parkopolis. Lastly, due to the constraints of observing children in different languages with minimal research staff, we prioritized observing Parkopolis groups which resulted in a much smaller sample size for the control condition.

Nonetheless, the pilot study accomplished its main objective to test whether children would play the game with minimal guidance and whether the game would elicit STEM language and adaptive learning behaviors. A larger version of Parkopolis is currently being fabricated for installation in Philadelphia, Pennsylvania.

\section{Discussion}

To date, we have proof of concept that Learning Landscapes projects can promote caregiver-child interactions and learning opportunities among children and families from low-income communities, while instilling community pride and civic engagement. The Learning Landscapes initiative takes an innovative approach to joining the pursuit of educational equity with the development of Conscious Cities in order to transform unexpected places into opportunities for playful learning. By combining principles from the science of learning about how people learn best with playful activities, Learning Landscapes projects target academic content in non-traditional settings. Learning Landscapes also takes a public health approach to education, embracing Rose's Theorem, which holds that a small dose of treatment disseminated widely to a large number of people has a larger net effect then more intensive treatment in a smaller population [101]. These interventions are low in individual effort and broad in their reach aligning with best practices in prevention science [102] and holding tremendous potential for widespread educational impact on children and families.

We began by asking if we could bring people together in a public space to explore playful learning in the Ultimate Block Party. UBP showed us that families are eager to learn more about educating their children outside of school and that interacting with as few as three playful learning activities can change their views of the potential for learning through play [51]. Next, we asked how trapped spaces, like supermarkets, could be infused with learning opportunities. Supermarket Speak demonstrated that signage in the places families spend their time can produce a meaningful boost in caregiver-child interactions in low-income neighborhoods [63]. Building on that investigation, we extended playful learning opportunities into public spaces. Urban Thinkscape is a model for community engagement and urban revitalization [81]. Finally, we developed a game to integrate even more sophisticated content into such public space installations. Parkopolis elicited the intended 
STEM language, engagement, and approaches to learning skills in an unsupervised setting that may generalize to city parks around the globe.

Projects of this sort are a way to add learning opportunities within the many city revitalization and urban renewal efforts that are mobilizing around the globe. The current projects do, however, have some general limitations. Among them, the current Learning Landscapes projects have not been able to generate data regarding child-learning outcomes. In our future projects, we will collect data at different levels, such as neighborhood data, family-level data using questionnaires and interviews, and child data as well. We posit that families living in neighborhoods that are saturated with Learning Landscapes will reveal positive changes in their beliefs about learning and play compared to families outside these zones. We have already begun to collect more detailed information about the impacts of Learning Landscapes on neighborhoods, families and children-essential to this endeavor based in the science of learning.

Somewhat similarly, we have not been able to tease apart exactly which prompts or activities made the difference in increasing caregiver-child discourse and engagement. Future research will work to determine if posing specific questions or including elements focusing on playful learning in specific content areas, such as science, mathematics, or language, provide the most impact.

Additionally, data collectors were not blind to conditions in the various Learning Landscape studies, because it is easy to see when signs or installations are either in place or not in place. Although every effort was made to ensure that data collectors were blind to study hypotheses, there is room for innovation in the types of data collection procedures used in these types of studies. For example, we are investigating installing usage sensors on outdoor projects to record how often an installation is manipulated throughout the course of the day. This would allow us to capture data that currently fall through the cracks when data collectors are not out at the site observing.

Also, it is important to comment on the nature of working on community-based research projects. Throughout the process of developing and implementing the suite of Learning Landscapes projects, we have learned a great deal about how to involve community members from the inception of a project all the way through data collection. We strive to better understand local needs with every successive study.

Even with these challenges and limitations, however, Learning Landscapes shows enormous promise for how we might capitalize on "the other $80 \%$ " of time when children are awake and not in school. If we are to move the needle on the glaring gaps between low- and middle-income children, city wide initiatives like Learning Landscapes are designed to be part of the solution. Only with bold efforts will we have a large enough dose to help all children thrive.

To date, we have only looked at the impact of individual projects on outcomes. As we build these installations into the fabric of the city, as we are doing in the new Philadelphia Playful Learning City project, we hypothesize that Learning Landscapes will also engender neighborhood-level effects, including building community knowledge of how young children learn best, the importance of play for learning, and the potential for turning public spaces into hubs that encourage children's learning and educational outcomes.

Author Contributions: B.H.D. and A.S.B. contributed equally to the conceptualization and writing of this article. K.H.P. and R.M.G. contributed equally to revision and developing the vision for the overall project.

Acknowledgments: This article was supported by funding from the William Penn Foundation (Grants 103-15 and 32-17) and an Institute for Education Sciences training grant (R305B150014).

Conflicts of Interest: The authors declare no conflict of interest. The financial sponsors had no role in the design of the study; in the collection, analyses, or interpretation of data; in the writing of the manuscript, and in the decision to publish the results.

\section{References}

1. Duncan, G.J.; Kalil, A.; Ziol-Guest, K.M. Increasing Inequality in Parent Incomes and Children's Schooling. Demography 2017, 54, 1603-1626. [CrossRef] [PubMed] 
2. Hair, N.L.; Hanson, J.L.; Wolfe, B.L.; Pollak, S.D. Association of Child Poverty, Brain Development, and Academic Achievement. JAMA Pediatr. 2015, 169, 822-829. [CrossRef] [PubMed]

3. Reardon, S.F. The widening income achievement gap. Educ. Leadersh. 2013, 70, 10-16.

4. Hoff, E. Interpreting the Early Language Trajectories of Children from Low SES and Language Minority Homes: Implications for Closing Achievement Gaps. Dev. Psychol. 2013, 49, 4-14. [CrossRef] [PubMed]

5. Verdine, B.N.; Golinkoff, R.M.; Hirsh-Pasek, K.; Newcombe, N.S.; Filipowicz, A.T.; Chang, A. Deconstructing Building Blocks: Preschoolers' Spatial Assembly Performance Relates to Early Mathematics Skills. Child Dev. 2014, 85, 1062-1076. [CrossRef] [PubMed]

6. Jordan, N.C.; Levine, S.C. Socioeconomic variation, number competence, and mathematics learning difficulties in young children. Dev. Disabil. Res. Rev. 2009, 15, 60-68. [CrossRef] [PubMed]

7. Yoshikawa, H.; Weiland, C.; Brooks-Gunn, J. When Does Preschool Matter? Future Child. 2016, 26, 21-35. [CrossRef]

8. Hill, C.J.; Gormley, W.T.; Adelstein, S. Do the short-term effects of a high-quality preschool program persist? Early Child. Res. Q. 2015, 32, 60-79. [CrossRef]

9. Weiland, C.; Yoshikawa, H. Impacts of a prekindergarten program on children's mathematics, language, literacy, executive function, and emotional skills. Child Dev. 2013, 84, 2112-2130. [CrossRef] [PubMed]

10. Meltzoff, A.N.; Kuhl, P.K.; Movellan, J.; Sejnowski, T.J. Foundations for a New Science of Learning. Science 2009, 325, 284-288. [CrossRef] [PubMed]

11. Golinkoff, R.M.; Hirsh-Pasek, K. Becoming Brilliant: What Science Tells Us about Raising Successful Children; American Psychological Association: Washington, DC, USA, 2016; ISBN 978-1-43-382239-1.

12. Weisberg, D.S.; Hirsh-Pasek, K.; Golinkoff, R.M. Guided play: Where curricular goals meet a playful pedagogy. Mind Brain Educ. 2013, 7, 104-112. [CrossRef]

13. UNICEF. The State of the World's Children 2012: Children in an Urban World; UNICEF: New York, NY, USA, 2012; ISBN 978-92-806-4597-2.

14. Brekke, H. How does the built environment affect behaviour and cognition? In Conscious Cities; 2016. Available online: https:/ / www.ccities.org/how-does-the-built-environment-affect-behaviour-andcognition/ (accessed on 22 May 2018).

15. Sumerling, B. A Place to play: An exploration of people's connection to local greenspace in East Leeds. In Conscious Cities; 2017. Available online: https://www.ccities.org/place-play-exploration-peoplesconnection-local-greenspace-east-leeds / (accessed on 22 May 2018).

16. Hirsh-Pasek, K.; Zosh, J.M.; Golinkoff, R.M.; Gray, J.H.; Robb, M.B.; Kaufman, J. Putting education in "educational" apps: Lessons from the science of learning. Psychol. Sci. Public Interest 2015, 16, 3-34. [CrossRef] [PubMed]

17. Weisberg, D.S.; Hirsh-Pasek, K.; Golinkoff, R.M.; Kittredge, A.K.; Klahr, D. Guided play: Principles and practices. Curr. Dir. Psychol. Sci. 2016, 25, 177-182. [CrossRef]

18. Hargrave, A.C.; Sénéchal, M. A book reading intervention with preschool children who have limited vocabularies: The benefits of regular reading and dialogic reading. Early Child. Res. Q. 2000, 15, 75-90. [CrossRef]

19. Zosh, J.M.; Brinster, M.; Halberda, J. Optimal Contrast: Competition Between Two Referents Improves Word Learning. Appl. Dev. Sci. 2013, 17, 20-28. [CrossRef]

20. Barr, R.; Shuck, L.; Salerno, K.; Atkinson, E.; Linebarger, D.L. Music interferes with learning from television during infancy. Infant Child Dev. 2010, 19, 313-331. [CrossRef]

21. Fisher, A.V.; Godwin, K.E.; Seltman, H. Visual Environment, Attention Allocation, and Learning in Young Children: When Too Much of a Good Thing May Be Bad. Psychol. Sci. 2014, 25, 1362-1370. [CrossRef] [PubMed]

22. Parish-Morris, J.; Mahajan, N.; Hirsh-Pasek, K.; Golinkoff, R.M.; Collins, M.F. Once upon a time: Parent-child dialogue and storybook reading in the electronic era. Mind Brain Educ. 2013, 7, 200-211. [CrossRef]

23. Tare, M.; Chiong, C.; Ganea, P.; Deloache, J. Less is more: How manipulative features affect children's learning from picture books. J. Appl. Dev. Psychol. 2010, 31, 395-400. [CrossRef] [PubMed]

24. Booth, A.E.; Waxman, S.R. Bringing theories of word learning in line with the evidence. Cognition 2003, 87, 215-218. [CrossRef]

25. Chi, M.T.H. Active-constructive-interactive: A conceptual framework for differentiating learning activities. Top. Cogn. Sci. 2009, 1, 73-105. [CrossRef] [PubMed] 
26. Csibra, G.; Gergely, G. Natural pedagogy. Trends Cogn. Sci. 2009, 13, 148-153. [CrossRef] [PubMed]

27. Kuhl, P.K.; Tsao, F.-M.; Liu, H.-M. Foreign-language experience in infancy: Effects of short-term exposure and social interaction on phonetic learning. Proc. Natl. Acad. Sci. USA 2003, 100, 9096-9101. [CrossRef] [PubMed]

28. Wu, R.; Gopnik, A.; Richardson, D.C.; Kirkham, N.Z. Infants learn about objects from statistics and people. Dev. Psychol. 2011, 47, 1220-1229. [CrossRef] [PubMed]

29. Fisher, K.; Hirsh-Pasek, K.; Golinkoff, R.M.; Singer, D.G.; Berk, L. Playing around in school: Implications for learning and educational policy. In The Oxford Handbook of the Development of Play; Nathan, P., Pellegrini, A.D., Eds.; Oxford Library of Psychology: Oxford, UK, 2010.

30. Johnson, J.E.; Christie, J.F.; Yawkey, T.D. Play and Early Childhood Development; Longman: New York, NY, USA, 1999; ISBN 978-0-32-101166-4.

31. Singer, D.G.; Singer, J.L. The House of Make-Believe: Children's Play and the Developing Imagination; Harvard University Press: Cambridge, MA, USA, 1990; ISBN 978-0-67-440874-8.

32. Henricks, T. The nature of play. Am. J. Play 2008, 1, 157-180.

33. Gopnik, A. Scientific thinking in young children: Theoretical advances, empirical research, and policy implications. Science 2012, 337, 1623-1627. [CrossRef] [PubMed]

34. Bonawitz, E.B.; Chang, I.Y.; Clark, C.; Lombrozo, T. Ockham's Razor as Inductive Bias in Preschooler's Causal Explanations. In Proceedings of the 2008 7th IEEE International Conference on Development and Learning, Monterey, CA, USA, 9-12 August 2008; pp. 7-12.

35. Schulz, L.E.; Bonawitz, E.B. Serious fun: Preschoolers engage in more exploratory play when evidence is confounded. Dev. Psychol. 2007, 43, 1045-1050. [CrossRef] [PubMed]

36. Bjorklund, D.F.; Gardiner, A.K. Object Play and Tool Use: Developmental and Evolutionary Perspectives. Psychol. Dev. Psychol. 2010. [CrossRef]

37. Jirout, J.; Klahr, D. Children's scientific curiosity: In search of an operational definition of an elusive concept. Dev. Rev. 2012, 32, 125-160. [CrossRef]

38. Kurkul, K.E.; Corriveau, K.H. Question, Explanation, Follow-Up: A Mechanism for Learning from Others? Child Dev. 2018, 89, 280-294. [CrossRef] [PubMed]

39. Legare, C.H.; Mills, C.M.; Souza, A.L.; Plummer, L.E.; Yasskin, R. The use of questions as problem-solving strategies during early childhood. J. Exp. Child Psychol. 2013, 114, 63-76. [CrossRef] [PubMed]

40. Sobel, D.M.; Sommerville, J.A. The Importance of Discovery in Children's Causal Learning from Interventions. Front. Psychol. 2010, 1, 176. [CrossRef] [PubMed]

41. Toub, T.S.; Rajan, V.; Golinkoff, R.M.; Hirsh-Pasek, K. Guided play: A solution to the play versus learning dichotomy. In Evolutionary Perspectives on Child Development and Education; Geary, D., Berch, D., Eds.; Springer International Publishing: Cham, Switzerland, 2016; pp. 117-141, ISBN 978-3-31-929986-0.

42. Han, M.; Moore, N.; Vukelich, C.; Buell, M. Does play make a difference? How play intervention affects the vocabulary learning of at-risk preschoolers. Am. J. Play 2010, 3, 82-105.

43. Roskos, K.A.; Burnstein, K. Assessment of the design efficacy of a preschool vocabulary instruction technique. J. Res. Child. Educ. 2011, 25, 268-287. [CrossRef]

44. Fisher, K.; Hirsh-Pasek, K.; Newcombe, N.; Golinkoff, R.M. Taking shape: Supporting preschoolers' acquisition of geometric knowledge through guided play. Child Dev. 2013, 84, 1872-1878. [CrossRef] [PubMed]

45. Garris, R.; Ahlers, R.; Driskell, J.E. Games, motivation, and learning: A research and practice model. Simul. Gaming 2002, 33, 441-467. [CrossRef]

46. Hassinger-Das, B.; Toub, T.S.; Zosh, J.M.; Michnick, J.; Golinkoff, R.; Hirsh-Pasek, K. More than just fun: A place for games in playful learning/Más que diversión: El lugar de los juegos reglados en el aprendizaje lúdico. Infanc. Aprendiz. 2017, 40, 191-218. [CrossRef]

47. Hassinger-Das, B.; Ridge, K.; Parker, A.; Golinkoff, R.M.; Hirsh-Pasek, K.; Dickinson, D.K. Building vocabulary knowledge in preschoolers through shared book reading and gameplay. Mind Brain Educ. 2016, 10, 71-80. [CrossRef]

48. Ramani, G.B.; Siegler, R.S. Promoting broad and stable improvements in low-income children's numerical knowledge through playing number board games. Child Dev. 2008, 79, 375-394. [CrossRef] [PubMed]

49. Neuman, S.B.; Celano, D. Access to Print in Low-Income and Middle-Income Communities: An Ecological Study of Four Neighborhoods. Read. Res. Q. 2001, 36, 8-26. [CrossRef] 
50. Weisberg, D.S.; Hirsh-Pasek, K.; Golinkoff, R.M.; McCandliss, B.D. Mise en place: Setting the stage for thought and action. Trends Cogn. Sci. 2014, 18, 276-278. [CrossRef] [PubMed]

51. Miller, E.; Almon, J. Crisis in the Kindergarten: Why Children Need to Play in School; Alliance for Childhood: College Park, MD, USA, 2009; ISBN 978-0-98-237510-5.

52. Grob, R.; Schlesinger, M.; Pace, A.; Golinkoff, R.M.; Hirsh-Pasek, K. Playing With Ideas: Evaluating the Impact of the Ultimate Block Party, a Collective Experiential Intervention to Enrich Perceptions of Play. Child Dev. 2017, 88, 1419-1434. [CrossRef] [PubMed]

53. Hirsh-Pasek, K.; Golinkoff, R.M. The great balancing act: Optimizing core curricula through playful learning. In The Pre-K Debates: Current Controversies and Issues; Zigler, E., Gilliam, W.S., Barnett, W.S., Eds.; Brookes Publishing Company: Baltimore, MD, USA, 2011; pp. 110-115.

54. Betancourt, L.M.; Avants, B.; Farah, M.J.; Brodsky, N.L.; Wu, J.; Ashtari, M.; Hurt, H. Effect of socioeconomic status (SES) disparity on neural development in female African-American infants at age 1 month. Dev. Sci. 2016, 19, 947-956. [CrossRef] [PubMed]

55. Johnson, S.B.; Riis, J.L.; Noble, K.G. State of the Art Review: Poverty and the Developing Brain. Pediatrics 2016, 137, e20153075. [CrossRef] [PubMed]

56. Cohen, D.A.; McKenzie, T.L.; Sehgal, A.; Williamson, S.; Golinelli, D.; Lurie, N. Contribution of public parks to physical activity. Am. J. Public Health 2007, 97, 509-514. [CrossRef] [PubMed]

57. Godbey, G.C.; Caldwell, L.L.; Floyd, M.; Payne, L.L. Contributions of leisure studies and recreation and park management research to the active living agenda. Am. J. Prev. Med. 2005, 28, 150-158. [CrossRef] [PubMed]

58. Payne, L.L.; Orsega-Smith, E.; Roy, M.; Godbey, G.C. Local Park Use and Personal Health among Older Adults: An Exploratory Study. J. Park Recreat. Adm. 2005, 23, 1-20.

59. Cohen, D.A.; Marsh, T.; Williamson, S.; Golinelli, D.; McKenzie, T.L. Impact and cost-effectiveness of family Fitness Zones: A natural experiment in urban public parks. Health Place 2012, 18, 39-45. [CrossRef] [PubMed]

60. Galinsky, E.; Bezos, J.; McClelland, M.; Carlson, S.M.; Zelazo, P.D. Civic Science for Public Use: Mind in the Making and Vroom. Child Dev. 2017, 88, 1409-1418. [CrossRef] [PubMed]

61. Bassok, D.; Finch, J.E.; Lee, R.; Reardon, S.F.; Waldfogel, J. Socioeconomic Gaps in Early Childhood Experiences: 1998 to 2010. AERA Open 2016, 2. [CrossRef]

62. Chak, A. Teachers' and parents' conceptions of children's curiosity and exploration. Int. J. Early Years Educ. 2007, 15, 141-159. [CrossRef]

63. Sigel, I.E. The belief-behavior connection: A resolvable dilemma. In Parental Belief Systems: The Psychological Consequences for Children; Sigel, I.E., McGillicuddy-De Lisi, A.V., Goodnow, J.J., Eds.; Lawrence Erlbaum Associates Publishers: Mahwah, NJ, USA, 1992; pp. 433-457.

64. Sigel, I.E.; McGillicuddy-De Lisi, A.V. Parent beliefs are cognition: The dynamic beliefs systems mode. In Handbook of Parenting: Being and Becoming a Parent; Bornstein, M., Ed.; Lawrence Erlbaum Associates Publishers: Mahwah, NJ, USA, 2002; Volume 3, pp. 485-508.

65. Zosh, J.M.; Fisher, K.; Golinkoff, R.M.; Hirsh-Pasek, K. The Ultimate Block Party: Bridging the science of learning and the importance of play. In Design, Make, and Play; Routledge: London, UK, 2013.

66. Ridge, K.E.; Weisberg, D.S.; Ilgaz, H.; Hirsh-Pasek, K.A.; Golinkoff, R.M. Supermarket Speak: Increasing Talk among Low-Socioeconomic Status Families. Mind Brain Educ. 2015, 9, 127-135. [CrossRef]

67. Rosnay, M.; Hughes, C. Conversation and theory of mind: Do children talk their way to socio-cognitive understanding? Br. J. Dev. Psychol. 2006, 24, 7-37. [CrossRef]

68. Brown, R. Development of the first language in the human species. Am. Psychol. 1973, 28, 97-106. [CrossRef]

69. Hirsh-Pasek, K.; Adamson, L.B.; Bakeman, R.; Owen, M.T.; Golinkoff, R.M.; Pace, A.; Yust, P.K.; Suma, K. The contribution of early communication quality to low-income children's language success. Psychol. Sci. 2015, 26, 1071-1083. [CrossRef] [PubMed]

70. Cristofaro, T.N.; Tamis-LeMonda, C.S. Mother-child conversations at 36 months and at pre-kindergarten: Relations to children's school readiness. J. Early Child. Lit. 2012, 12, 68-97. [CrossRef]

71. Tamis-LeMonda, C.S.; Bornstein, M.H.; Baumwell, L. Maternal responsiveness and children's achievement of language milestones. Child Dev. 2001, 72, 748-767. [CrossRef] [PubMed]

72. Deutscher, B.; Fewell, R.R.; Gross, M. Enhancing the interactions of teenage mothers and their at-risk children: Effectiveness of a maternal-focused intervention. Top. Early Child. Spec. Educ. 2006, 26, 194-205. [CrossRef]

73. Letourneau, N. Attrition among adolescents and infants involved in a parenting intervention. Child Care Health Dev. 2001, 27, 183-186. [CrossRef] [PubMed] 
74. Eyberg, S.M.; Nelson, M.M.; Ginn, N.C.; Bhuiyan, N.; Boggs, S.R. Dyadic Parent-Child Interaction Coding System; PCIT International: Gainesville, FL, USA, 2013.

75. Morris, A.; Zapata, M.; Treat, A. Talking is Teaching in supermarkets. In Proceedings of the International Congress of Infant Studies Biennial Meeting, Philadelphia, PA, USA, 30 June-3 July 2018.

76. Radesky, J.S.; Kistin, C.J.; Zuckerman, B.; Nitzberg, K.; Gross, J.; Kaplan-Sanoff, M.; Augustyn, M.; Silverstein, M. Patterns of mobile device use by parents and children during meals in fast food restaurants. Pediatrics 2014. [CrossRef] [PubMed]

77. Classens, A.; Engel, M. How important is where you start? Early mathematics knowledge and later school success. Teach. Coll. Rec. 2013, 115, 1-29.

78. Verdine, B.N.; Irwin, C.M.; Golinkoff, R.M.; Hirsh-Pasek, K. Contributions of executive function and spatial skills to preschool mathematics achievement. J. Exp. Child Psychol. 2014, 126, 37-51. [CrossRef] [PubMed]

79. Tabors, P.O.; Snow, C.E.; Dickinson, D.K. Homes and schools together: Supporting language and literacy development. In Beginning Literacy with Language: Young Children Learning at Home and School; Paul H Brookes Publishing: Baltimore, MD, USA, 2011; pp. 1-25.

80. Blair, C.; Razza, R.P. Relating effortful control, executive function, and false belief understanding to emerging math and literacy ability in kindergarten. Child Dev. 2007, 78, 647-663. [CrossRef] [PubMed]

81. Hassinger-Das, B.; Toub, T.S.; Hirsh-Pasek, K.; Golinkoff, R.M. A matter of principle: Applying language science to the classroom and beyond. Transl. Issues Psychol. Sci. 2017, 3, 5. [CrossRef]

82. Siegler, R.S.; Ramani, G.B. Playing linear numerical board games promotes low-income children's numerical development. Dev. Sci. 2008, 11, 655-661. [CrossRef] [PubMed]

83. Siegler, R.S.; Opfer, J.E. The development of numerical estimation: Evidence for multiple representations of numerical quantity. Psychol. Sci. 2003, 14, 237-250. [CrossRef] [PubMed]

84. Dackermann, T.; Fischer, U.; Nuerk, H.C.; Cress, U.; Moeller, K. Applying embodied cognition: From useful interventions and their theoretical underpinnings to practical applications. Zdm 2017, 49, 545-557. [CrossRef]

85. Fischer, U.; Moeller, K.; Class, F.; Huber, S.; Cress, U.; Nuerk, H.C. Dancing with the SNARC: Measuring spatial-numerical associations on a digital dance mat. Can. J. Exp. Psychol. 2016, 70, 306. [CrossRef] [PubMed]

86. Link, T.; Moeller, K.; Huber, S.; Fischer, U.; Nuerk, H.C. Walk the number line-An embodied training of numerical concepts. Trends Neurosci. Educ. 2013, 2, 74-84. [CrossRef]

87. Jordan, N.C.; Resnick, I.; Rodrigues, J.; Hansen, N.; Dyson, N. Delaware longitudinal study of fraction learning: Implications for helping children with mathematics difficulties. J. Learn. Disabil. 2017, 50, 621-630. [CrossRef] [PubMed]

88. Rittle-Johnson, B.; Fyfe, E.R.; Loehr, A.M.; Miller, M.R. Beyond numeracy in preschool: Adding patterns to the equation. Early Child. Res. Q. 2015, 31, 101-112. [CrossRef]

89. Geist, K.; Geist, E.A.; Kuznik, K. The patterns of music: Young children learning mathematics through beat, rhythm, and melody. YC Young Child. 2012, 67, 74.

90. Sarama, J.; Clements, D.H. Building blocks for young children's mathematical development. J. Educ. Comput. Res. 2002, 27, 93-110. [CrossRef]

91. Clements, D.H. Geometric and spatial thinking in early childhood education. In Engaging Young Children in Mathematics: Standards for Early Childhood Mathematics Education; Routledge: Abingdon, UK, 2004; pp. 267-297.

92. Geary, D.C.; Bailey, D.H.; Hoard, M.K. Predicting mathematical achievement and mathematical learning disability with a simple screening tool: The number sets test. J. Psychoeduc. Assess. 2009, 27, 265-279. [CrossRef] [PubMed]

93. Clements, D.H.; Wilson, D.C.; Sarama, J. Young children's composition of geometric figures: A learning trajectory. Math. Think. Learn. 2004, 6, 163-184. [CrossRef]

94. Szilágyi, J.; Clements, D.H.; Sarama, J. Young children's understandings of length measurement: Evaluating a learning trajectory. J. Res. Math. Educ. 2013, 44, 581-620. [CrossRef]

95. Fuchs, L.S.; Schumacher, R.F.; Long, J.; Namkung, J.; Malone, A.S.; Wang, A.; Hamlett, C.L.; Jordan, N.C.; Siegler, R.S.; Changas, P. Effects of intervention to improve at-risk fourth graders' understanding, calculations, and word problems with fractions. Elem. Sch. J. 2016, 116, 625-651. [CrossRef]

96. Diamond, A.; Lee, K. Interventions shown to aid executive function development in children 4 to 12 years old. Science 2011, 333, 959-964. [CrossRef] [PubMed] 
97. Fantuzzo, J.W.; Gadsden, V.L.; McDermott, P.A. An integrated curriculum to improve mathematics, language, and literacy for Head Start children. Am. Educ. Res. J. 2011, 48, 763-793. [CrossRef]

98. Green, C.T.; Bunge, S.A.; Chiongbian, V.B.; Barrow, M.; Ferrer, E. Fluid reasoning predicts future mathematical performance among children and adolescents. J. Exp. Child Psychol. 2017, 157, 125-143. [CrossRef] [PubMed]

99. Verburgh, L.; Königs, M.; Scherder, E.J.; Oosterlaan, J. Physical exercise and executive functions in preadolescent children, adolescents and young adults: a meta-analysis. Br. J. Sports Med. 2013. [CrossRef] [PubMed]

100. Jones, R.A.; Hinkley, T.; Okely, A.D.; Salmon, J. Tracking physical activity and sedentary behavior in childhood: a systematic review. Am. J. Prev. Med. 2013, 44, 651-658. [CrossRef] [PubMed]

101. Rose, G. Strategy of prevention: Lessons from cardiovascular disease. Br. Med. J. 1981, 282, $1847-1851$. [CrossRef]

102. Frieden, T.R. A framework for public health action: The health impact pyramid. Am. J. Public Health 2010, 100, 590-595. [CrossRef] [PubMed]

(c) 2018 by the authors. Licensee MDPI, Basel, Switzerland. This article is an open access article distributed under the terms and conditions of the Creative Commons Attribution (CC BY) license (http://creativecommons.org/licenses/by/4.0/). 